\title{
OS ALVÉOLOS GRANÍTICOS DO PORTUGAL CENTRAL: MORFOGÊNESE E ANÁLISE TIPOLÓGICA DO MODELADO DE DEGRADAÇÃO DAS SUPERFÍCIES APLANADAS
}

\author{
ALVEOLAR WEATHERING BASINS IN GRANITE IN CENTRAL \\ PORTUGAL: MORPHOGENESIS AND TYPOLOGICAL ANALYSIS OF \\ WEATHERING FORMS IN LEVELLED LANDSCAPES
}

\author{
António Manuel Rochette Cordeiro \\ Departamento de Geografia, Faculdade de Letras da Universidade de Coimbra \\ Largo da Porta Férrea, Coimbra, Cep: 3004-530, Portugal \\ E-mail: rochettecordeiro@fl.uc.pt
}

\section{Informações sobre o Artigo}

Data de Recebimento:

$31 / 05 / 2014$

Data de Aprovação:

15/08/2014

Palavras-chave:

Geomorfologia granítica;

Portugal Central; Tipologia

alveolar; Génese e evolução

\section{Keywords:}

Granite geomorphology; Central Portugal; Typology, Genesis and evolution of weathering basins

\section{Resumo:}

As bacias de meteorização química de escala média, ou "alvéolos graníticos" quando entendidos no sentido que Alain Godard lhe conferiu, constituem-se como um dos elementos fundamentais na interpretação da morfologia granítica portuguesa. Em termos morfológicos, assumem-se como bacias arredondadas, relativamente circunscritas, revestidas por um manto de alteração com espessura variável e com uma dimensão que vai desde as centenas de metros até à dimensão quilométrica. A alveolização é o resultado de um compromisso morfogenético entre fases de alteração química em clima tropical húmido e fases de ablação em clima subtropical seco, encontrando-se a sua génese associada a fatores morfoestruturais, enquanto a sua diferenciação se deve, no essencial, a fatores morfoclimáticos. O objetivo fulcral do trabalho passa pelo demonstrar que, em condições de base estrutural idênticas, se observa uma diferenciação morfológica entre as formas alveolares dos setores do litoral e do interior do Portugal Central, e que assumida como resultante da eficácia dos processos morfogenéticos (meteorização química) no quadro das diferenças observadas em torno das condições climáticas entre os dois setores. Em termos metodológicos, ao longo das duas décadas em que os distintos trabalhos foram desenvolvidos, foi o trabalho de campo e a fotointerpretação que estiveram na base da elaboração de cartografia geomorfológica de pormenor, associando-se análises químicas e de porosidades, ou lâminas delgadas, entre muitas outras técnicas laboratoriais, a que os diferentes autores recorreram. A existência de vários tipos de alvéolos - elementares, complexos, corredores de erosão e mistos - mostra que muitos outros fatores têm de ser tomados em consideração na compreensão do processo de alveolização. 


\begin{abstract}
:
Medium-size chemical weathering basins, or "alvéoles granitiques", in Alain Godard's sense, are fundamental for interpreting Portuguese granite morphology. In morphological terms, they are round-shaped, relatively circumscribed, covered by a crust of altered sediment of variable thickness and size - ranging from a few hundred meters to kilometers. Weathering basins are the result of a morphogenetic commitment between periods of chemical alteration in humid tropical climate and periods of ablation in dry subtropical climate. Therefore, their genesis is associated with morphostructural factors, while differentiation is essentially due to morphoclimatic factors. The central objective of this study is to demonstrate that, in similar structural conditions, one observes morphological differentiation between the weathering forms of the littoral and interior of Central Portugal, and this was considered to be the result of the efficacy of morphogenetic processes (chemical weathering), in the context of the differences observed in climate conditions in the two sectors. In methodological terms, throughout the two decades in which work was carried out, geomorphological maps were drawn on the basis of fieldwork and photo interpretation, associated with chemical and porosity analyses, or thin sections, among many other laboratory techniques used by the different authors. The existence of different types of weathering forms - elementary, complex, erosion channels and mixed - shows that other factors have to be taken into account to understand the process of alveolar weathering in Central Portugal.
\end{abstract}

\section{Enquadramento Geral do Território e da Temática}

A análise, inventariação e sistematização do modelado granítico do Centro de Portugal tem vindo a ser, ao longo das últimas décadas, âmbito de trabalho de alguns geomorfólogos.

Num contexto regional, alguns estudos foram publicados sobre as grandes linhas do modelado deste sector do território nacional que em muito marcaram a geomorfologia portuguesa desde meados do século passado (Birot, 1949; Ribeiro, 1949; 1954; Ferreira, 1978A; 1978B; 1980; 1991; Cunha, 1992; Gomes, 2008). Por seu turno, e já num contexto de evidente descida na escala de análise, muitos outros se debruçaram sobre as formas graníticas de dimensão média e as microformas (Ferreira, 1978a; 1978b; Rebelo, 1991; Pedrosa, 1991; 1993; Cordeiro, 1988; 1991; 1995a; 1995b; 1999a; 1999b; 2004; Cordeiro e Rebelo, 1996; Rebelo e Cordeiro, 1997; Cordeiro et al., 2007; Vieira, 2008; 2010; Clamote, 2011), tornando possível a crescente sistematização do modelado granítico do Portugal Central.

As caraterísticas morfoestruturais deste setor do território português, com as baixas altitudes a dominarem o setor oeste onde se desenvolvem os diferentes materiais sedimentares da Orla Ocidental em contraste com os materiais magmáticos e metassedimentares do Maciço Hespérico no setor central e oriental, caraterizado nesta área por amplos planaltos, muitas vezes desnivelados por ação da tectónica, confere-lhe particularidades muito singulares no contexto morfológico português (Figura 1). Deste modo, pode afirmar-se que a morfologia do centro interior de Portugal resulta de um compromisso entre os vastos níveis de aplanamento decorrentes das superfícies aplanadas que se desenvolveram ao longo do Mesozoico e parte do Cenozoico e o seu desnivelamento e compartimentação por ação da tectónica alpina, dando origem, entre outras, às Montanha Ocidentais e à Cordilheira Central, bem como à individualização da superfície da Meseta e dos diferentes Planaltos da Beira.

Num quadro morfoestrutural como o observado, existiriam assim, em determinados momentos da história geológica ibérica, condições para o desenvolvimento de todo um conjunto de processos morfogenéticos que levaram à formação das anteriormente designadas "bacias marginais de génese climática" (Cordeiro, 1995a) -, formas de média escala ligadas à degradação de superfícies aplanadas em rochas cristalinas e que foram designadas por A. Godard (1977) como os "alvéolos graníticos". Ganhando uma importância decisiva no contexto da interpretação da evolução geomorfológica deste setor do território português, este modelado foi interpretado como fortemente associado a condicionalismos de ordem estrutural (tectónica e litologia) deixando porém, adivinhar a influência das condições morfoclimáticas durante um período significativo que caraterizou os finais do Cenozoico, tal como foi referido 

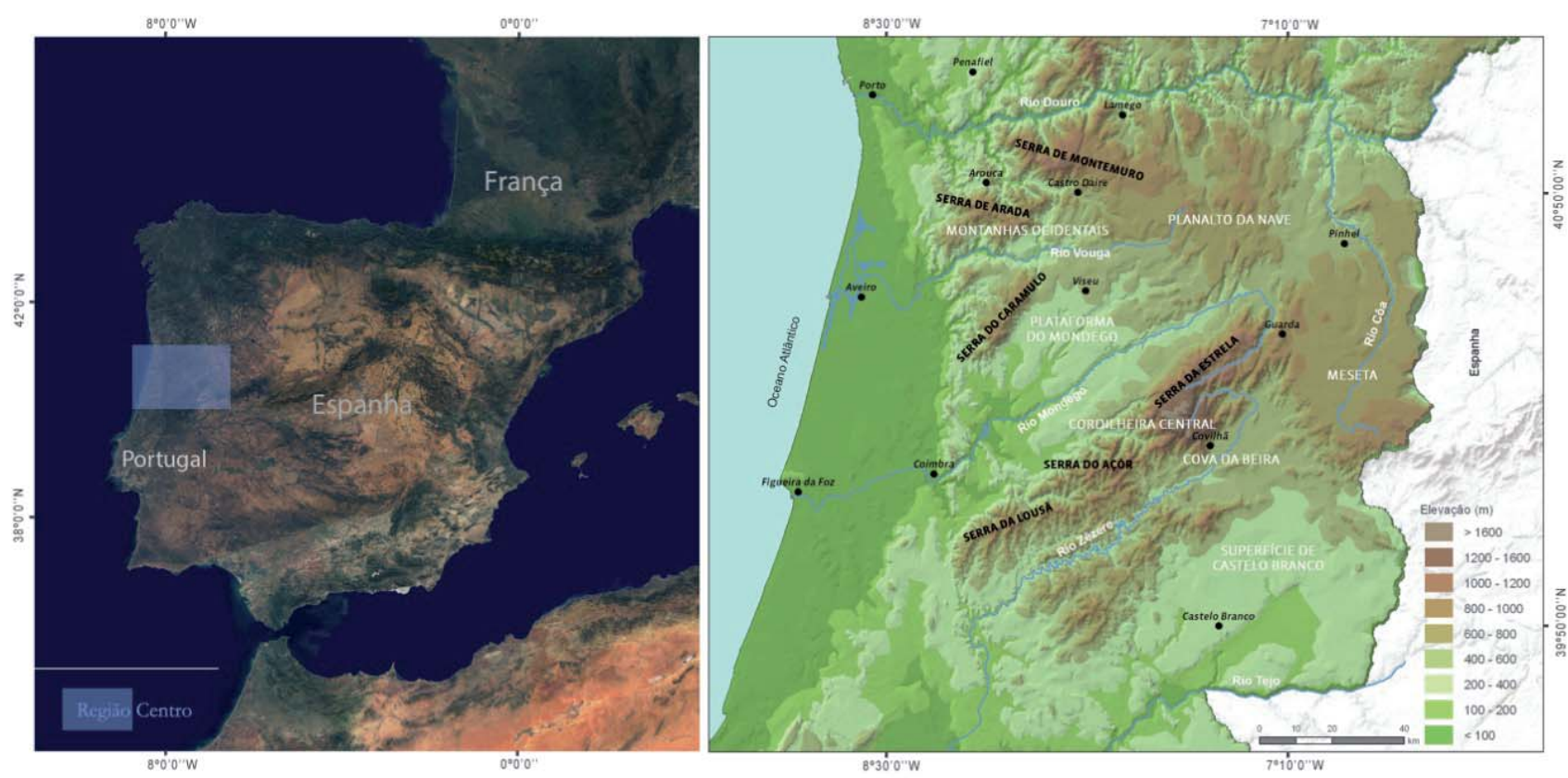

Figura 1 - Enquadramento do Portugal Central.

por Cordeiro (2004). Apresentando-se como um dos mais importantes modelados nos estudos geomorfológicos em áreas graníticas de regiões mediterrâneas ou de influências mediterrâneas, o relevo alveolar observa-se, no essencial, em função do desenvolvimento de uma erosão diferencial, tanto em sectores graníticos como nas áreas de contacto entre as rochas granitoides e as envolventes.

Estudos anteriores referiam já os alvéolos graníticos do território português a norte do rio Mondego: Birot (1949), Godard (1977), Ferreira (1978B), CoudéGaussen (1981), Pedrosa (1991; 1993) e Soares (1992), referiram-se aos alvéolos minhotos (norte litoral de Portugal), enquanto Ferreira (1978A), Birot et al. (1979), Cordeiro (1986; 1988; 1991; 1995B; 1995C; 2004), Vieira (2008; 2010) e Gomes (2008) desenvolveram ou afloraram a temática exclusivamente sobre os alvéolos a sul do rio Douro e, em particular, no litoral. Contudo, outros sectores do Portugal Central apresentam esta mesma tipologia de modelado, como os identificados no interior de Portugal, mais propriamente no rebordo da Meseta Ibérica (Clamote, 2011), pelo que estas formas são identificadas em vários contextos espaciais e com morfologias muito diferenciadas.

A diversidade de posicionamento das superfícies aplanadas definidas por Ferreira (1978a) para o Portugal
Central, bem como a diversidade litológica e as suas relações com o nível de base, motivaram diferenciações bem nítidas nos alvéolos deste amplo setor do território português.

\subsection{Procedimentos metodológicos}

O objetivo fulcral deste trabalho prende-se com o revisitar crítico da tipologia alveolar do território do Centro de Portugal, procurando assumir o que há muito se vinha constatando: a condições morfo-estruturais idênticas, corresponde um modelado diferenciado (forma, dimensão, espessura da alterite e profundidade) conforme o seu posicionamento face à proximidade do oceano. Os procedimentos metodológicos desenvolvidos para o concretizar deste trabalho de síntese, tiveram em consideração as premissas que levaram às primeiras sistematizações sobre a tipologia dos alvéolos graníticos no Portugal Central (Cordeiro, 1995a; 2004), e que seguiram os diferentes protocolos de análise disponíveis na altura e que foram articulados com os procedimentos associados aos trabalhos entretanto realizados - Vieira (2008) e Clamote (2011).

Para o estudo deste modelado associado à degradação das superfícies aplanadas desenvolvidas no decorrer da longa fase de acalmia da tectogénese do 
Mesozoico e do Cenozoico os procedimentos passaram não só pela revisão bibliográfica (quer temática, quer de índole regional), mas também por um longo trabalho de fotointerpretação, a partir do qual resultou a elaboração de cartografia geomorfológica (utilizando para tal distintas extensões de arcgis) dos diferentes setores da Região Centro. Porém, em todo o processo de elaboração dos diferentes trabalhos sobre a temática do modelado granítico, foram desenvolvidas análises de porosidade de rochas (protocolo CNRS-Caen), análises da composição química dos batólitos ou a realização de lâminas delgadas, e às quais se associou, em todas as fases do processo de análise do modelado, um exaustivo trabalho de campo.

\section{Principais Fatores Associados à Morfogénese dos Alvéolos}

A alveolização, apresenta-se como um processo de compromisso entre a arenitização das rochas graníticas, resultante de uma importante alteração química associadas a um modelado de duas superfícies (fundamentalmente desenvolvido em períodos de caraterísticas tropicais húmidas) e a evacuação "violenta e espasmódica" desses mesmos materiais alterados (relacionada com chuvas concentradas, que A. Godard associava a climas subtropicais semiáridos), desenvolvendo-se as formas, associadas à existência de uma erosão diferencial nos sectores anteriormente aplanados, as quais no seu momento terminal se terão assumido como de etchplains (Cordeiro, 2004). O ataque químico motiva assim o aprofundamento da superfície basal de meteorização após o início da degradação da superfície de aplanamento anterior, vindo a ter maior eficácia sempre que a temperatura e a humidade fossem elevadas, no mínimo durante uma época do ano (Büdel, 1970; Thomas, 1974; 1994; Godard, 1977; Twidale, 1982; 2002; Romani e Twidale, 1998).

\subsection{A estrutura e o relevo alveolar}

\subsubsection{O peso da litologia}

A distribuição espacial dos alvéolos pelas diferentes manchas graníticas do Centro-Norte de Portugal demonstra, de um modo imediato, o peso da componente litológica na distribuição espacial deste modelado (Figura 2). A composição químico-mineralógica, a poro- sidade, a fissuração e a textura das rochas apresentam-se assim como fatores decisivos na sensibilidade à alteração química.

Nesse sentido, J. J. Lagasquie (1984a; 1984b), nos seus trabalhos sobre o modelado granítico dos Pirenéus, colocou em evidência as "regras" de alteração das rochas granitóides: os gabros, os dioritos e os "monzogranitos" apresentariam elevada resistência, enquanto os quartzodioritos e os granodioritos se mostrariam frágeis e muito alteráveis. No caso português, a análise e observação do desenvolvimento e amplitude dos processos de alveolização foram realizados sob dois prismas: por um lado, a análise ao nível das diferentes manchas graníticas e, por outro, as diferenças existentes ao nível do mesmo tipo de granitoides, de preferência no mesmo batólito.

Deste modo, e quando observado apenas o setor mais ocidental do centro de Portugal, constata-se que as formas mais espetaculares (e também em maior número) se vão encontrar no batólito quartzodiorítico de Arouca, no plutonito do Caramulo e ainda na faixa blastomilonítica de Oliveira de Azeméis (Cordeiro, 2004). Em contrapartida, o número e a dimensão dos alvéolos, na maior mancha granítica existente na área (faixa granítica de Póvoa do Varzim-Porto-Viseu), apresenta um número diminuto (Figura 2).

Para a análise comparativa entre diferentes granitóides, tomaram-se como base neste trabalho os pequenos batólitos de Arouca e Regoufe (área próxima de Arouca na vertente norte da serra da Arada/Freita). Ambos são tardi a pós orogénicos Relativamente à orogenia Varisca) e os seus parâmetros geoquímicos apresentados por Pinto (1985), mostram, com base nas análises químicas, normas e índices de diferenciação destes mesmos granitóides, uma diferenciação das condições de base que levaram ao aparecimento destas formas. A existência de uma forte tendência para a alveolização no batólito de Arouca (com o aparecimento dos alvéolos de Arouca, Moldes e Rossas) parece reforçar a ideia da importância relativa da sua composição química, designadamente a presença de anortite na efetividade do processo. O quartzodiorito de Arouca apresenta valores elevados desta plagióclase cálcica (entre 11,24 e 15,48\%) ao passo que no granito de Regoufe os valores encontrados são baixos (0,62 a $0,88 \%)$. No mesmo sentido, encontram-se valores mais elevados das componentes ferromagnesianas (Ferro 


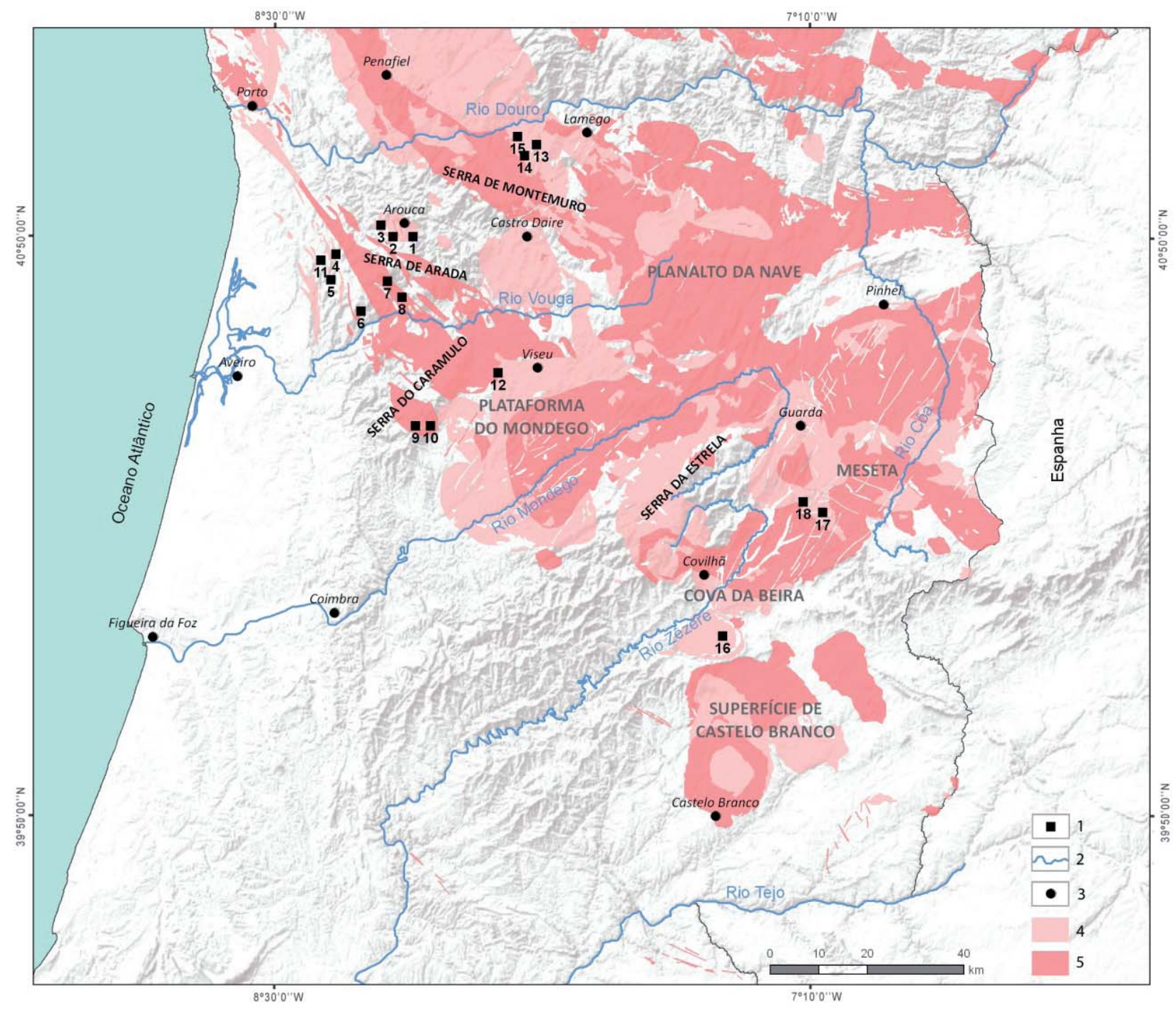

Figura 2 - Localização das principais formas alveolares e a sua relação com as rochas graníticas do Portugal Central.

Legenda: 1 - Alvéolos; 2 - Principais cursos de água; 3 - Principais aglomerados populacionais; 4 - Rochas granitóides biotíticas; 5 Rochas granitóides não biotíticas

Principais alvéolos: 1 - Moldes; 2 - Arouca; 3 - Rossas; 4 - Vila Cova Perrinho; 5 - Ossela; 6 - Silva Escura; 7 - Linhares; 8 - Arestal; 9 - Almofala; 10 - Dornas; 11 - Corredor de Erosão de Vale de Cambra; 12 - Queirã; 13 - Feirão; 14 - Lagoa de S. João; 15 - Lagoa Pequena; 16 - Fundão; 17 - Penalobo; 18 - Água da Figueira.

total e $\mathrm{MgO}$ ) no quartzodiorito, enquanto os valores de sílica e quartzo são mais elevados no granito de Regoufe. Poderá, assim referir-se que o quartzodiorito de Arouca, sob o ponto de vista unicamente da sua composição químico-mineralógica, se apresenta como um granitóide mais alterável do que o granito de Regoufe.

Já quando de uma análise ao nível de um mesmo batólito, merece referência o plutonito do Caramulo (serra mais a sul das Montanhas Ocidentais - cfr. Figura 2): o aparecimento de pequenos alvéolos no seu sector sueste (Almofala e Dornas) poderá ser justificado, entre outras razões, pela existência de pequenas nuances do ponto de vista mineralógico. A amostra recolhida junto à depressão onde se localiza a povoação de Almofala, o valor da biotite $(6,8 \%)$ é praticamente o dobro dos observados nos restantes casos (mesmo nos que se encontram à sua volta), enquanto o valor do feldspato potássico é dos mais baixos $(19,2 \%)$ de todos os encontrados no total do plutonito (Godinho, 1980).

Deste modo, e em sintonia com o índice de alterabilidade (e mesmo tendo em consideração que existem outros fatores estruturais fundamentais no desenvolvi- 
mento dos alvéolos), constata-se que do ponto de vista químico-mineralógico, o "quartzodiorito de Arouca", ou o "granito de Almofala" são materiais mais suscetíveis à meteorização que os granitos envolventes.

Contudo, e embora os contrastes químico-mineralógicos sejam determinantes, estes não são os únicos elementos na compreensão dos processos de alteração, uma vez que outros fatores intervêm, como são os casos da ordenação ou arranjo dos minerais e a heterogeneidade da dimensão dos grãos, ou o papel da textura. Assim, a título de exemplo, a presença da biotite em percentagens elevadas, relativamente à horneblenda, parece provocar uma maior tendência para a fratura dos grãos da rocha sã (Thomas, 1974; Lagasquie, 1984a; 1984b), algo que facilmente se constata, por exemplo, no batólito de Arouca.

$\mathrm{Na}$ alterabilidade das rochas granitóides, parece também ser inquestionável o facto da porosidade global se constituir como um parâmetro extremamente importante na compreensão das descontinuidades das rochas à escala microscópica, já que vai assegurar a penetração da água, atuando como um dos principais fatores de alteração diferencial (Coque-Delhuille, 1981).

Neste contexto, tome-se como exemplo os atrás referidos granitóides que se encontram no sector ocidental e central das Montanhas Ocidentais: o granito de grão médio de S. Pedro Velho (o qual ocupa uma grande percentagem das áreas aplanadas culminantes da serra da Arada/Freita e da área de Nabais) e o quartzodiorito de Arouca, assim como dos xistos envolventes (Cordeiro, 2004). Os resultados obtidos parecem mostrar uma relação estreita entre os valores de porosidade e o desenvolvimento dos alvéolos, em particular os de grande dimensão. A comparação dos valores de porosidade verificados entre os três tipos de rocha repete uma relação já anteriormente sentida: o granito de S. Pedro Velho apresenta valores bastante baixos (com média inferior aos 5\%). Por sua vez, o quartzodiorito de Arouca apresenta os valores médios superiores a 6, $8 \%$, encontrando-se, mesmo, valores de cerca de $13 \%$ (Quadro 1).

Como facilmente se observa, o quartzodiorito de Arouca continua a mostrar-se, em função dos fatores de alterabilidade, como a rocha que mais facilmente permitirá o desenvolvimento da alveolização.

Esta predisposição sai, neste caso, reforçada por um outro fator que foi referido por Lagasquie (1984A) e Cordeiro (1995b): as modificações petrográficas e estruturais dos estádios tardios da ascensão magmática apresentam-se como um importante fator na resistência das margens de um batólito, para além dos setores resistentes serem formados habitualmente por corneanas. A existência nas margens dos corpos intrusivos de uma auréola de metamorfismo de contacto com diferente petrografia e mais resistentes à erosão, provoca uma maior dificuldade de penetração da água na rocha, bem como, nos casos relacionados com os cursos de água, uma maior retenção de água a montante dessas soleiras de rocha mais dura, com uma consequente alteração química no interior do batólito.

A importância deste facto no desenvolvimento dos alvéolos é magnificamente ilustrada pela existência no batólito de Arouca de uma auréola metamórfica, bem nítida nas margens oeste e norte do corpo intrusivo,

Quadro 1: Valores de porosidade do granito de S. Pedro Velho, do quartzodiorito de Arouca e dos xistos metamórficos do Destrelo da Malhada (serra da Freita).

\begin{tabular}{|c|c|c|c|c|c|}
\hline \multicolumn{2}{|c|}{ Xistos metamórficos } & \multicolumn{2}{|c|}{ Quartzodiorito de Arouca } & \multicolumn{2}{|c|}{ Gran. de S. P. Velho } \\
\hline Amostra & Porosidade & Amostra & Porosidade & Amostra & Porosidade \\
\hline 1 & 6.34 & $2 a$ & 3.78 & $3 a$ & 4.12 \\
\hline 2 & 6.86 & $2 \mathrm{~b}$ & 6.86 & $3 \mathrm{~b}$ & 4.83 \\
\hline 1 b 1 & 7.26 & $2 \times 1$ & 4.13 & $3 \mathrm{c}$ & 6.21 \\
\hline $1 b 2$ & 8.88 & $2 d$ & 13.17 & $3 d$ & 6.98 \\
\hline $1 c$ & 8.68 & $2 e$ & 10.58 & $3 e$ & 4.89 \\
\hline $1 \mathrm{~d} 1$ & 7.66 & 1 & 8.83 & $3 f$ & 2.48 \\
\hline 1 e 1 & 8.12 & 2 & 7.62 & $3 g$ & 4.57 \\
\hline 1 e 2 & 7.47 & 1 & 3.4 & $3 \mathrm{~h} 1$ & 4.79 \\
\hline $1 \mathrm{f}$ & 7.76 & 2 & 3.46 & 3 h 3 & 4.92 \\
\hline
\end{tabular}


condicionando fortemente o aparecimento do grande alvéolo de Arouca (Cordeiro, 1988; 1995b; 2004). Esta mesma relação de eficácia da alteração química, provocada pela retenção da água por parte da rocha menos afetada por aquele processo, parece verificar-se também no caso da existência de cristas quartzíticas a jusante dos batólitos, algo que se observa claramente no setor que vai de Vale de Cambra a Cesar (lugar localizado a $9 \mathrm{~km}$ a NNE de Vale de Cambra).

\subsubsection{A influência da tectónica}

A incisão e, em especial, o facto da orientação dos cursos de água em áreas graníticas resultar da exploração de fraturas e falhas que facilitam e guiam a penetração da alteração, levam a que as áreas intensamente fraturadas sejam alvo preferencial da meteorização química (Feio e Brito, 1950; Thomas, 1974; Godard, 1977; Ferreira, 1978B; Coudé-Gaussen, 1981; Cordeiro, 2004).
A análise da localização dos alvéolos relativamente à tectónica realça este facto, uma vez que a esmagadora maioria dos alvéolos se encontra relacionada com um ou vários alinhamentos tectónicos, facto bem documentado em praticamente todos os exemplos encontrados no setor litoral, nomeadamente nas áreas de Arouca (Figura 3) e na depressão de Vale de Cambra-Romariz (Figura 4). Estas duas grandes formas alveolares (pluriquilométricas) desenvolvem os seus eixos principais segundo alinhamentos tectónicos bem definidos. Por contraponto, à complexidade estrutural e litológica existente na faixa de Oliveira de Azeméis contrapõe-se a simplicidade do batólito de Arouca. Assim, a ampla forma existente entre Romariz e Castelões (Vale de Cambra), que se desenvolve quer em rochas granitóides com forte componente biotítica, quer em metassedimentos do "Complexo xistograuváquico" (neste sector encontram-se bastante fragmentados e com injeções de materiais gnaissicos), apresenta como acidente principal a falha Silva Escura - Cesár.

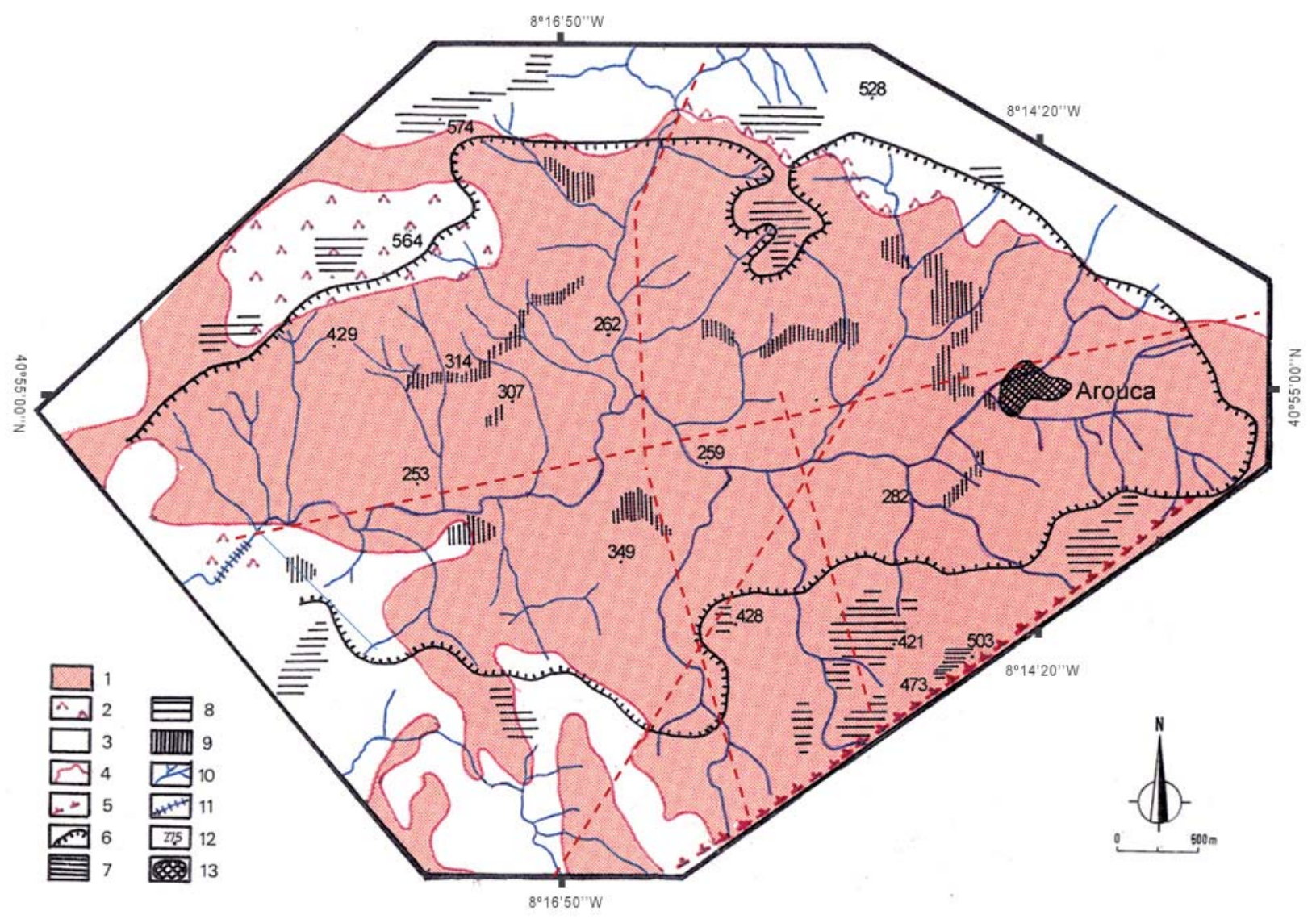

Figura 3 - Alvéolo complexo de Arouca - esboço simplificado

Legenda - 1 Quartzodiorito; 2 - Corneanas; 3 -Xistos; 4 - Limite do batólito de Arouca; 5 - Escarpa de falha provável; 6 - Limite do Alvéolo de Arouca; 7 - Níveis que dominam o alvéolo - bem conservado; 8 - Níveis que dominam o alvéolo - mal conservado; 9 - Níveis inferiores do alvéolo; 10 - Cursos de água; 11 - Garganta de saída do alvéolo; 12 - Pontos cotados; 13 - Povoação. 
Cordeiro A. M. R.

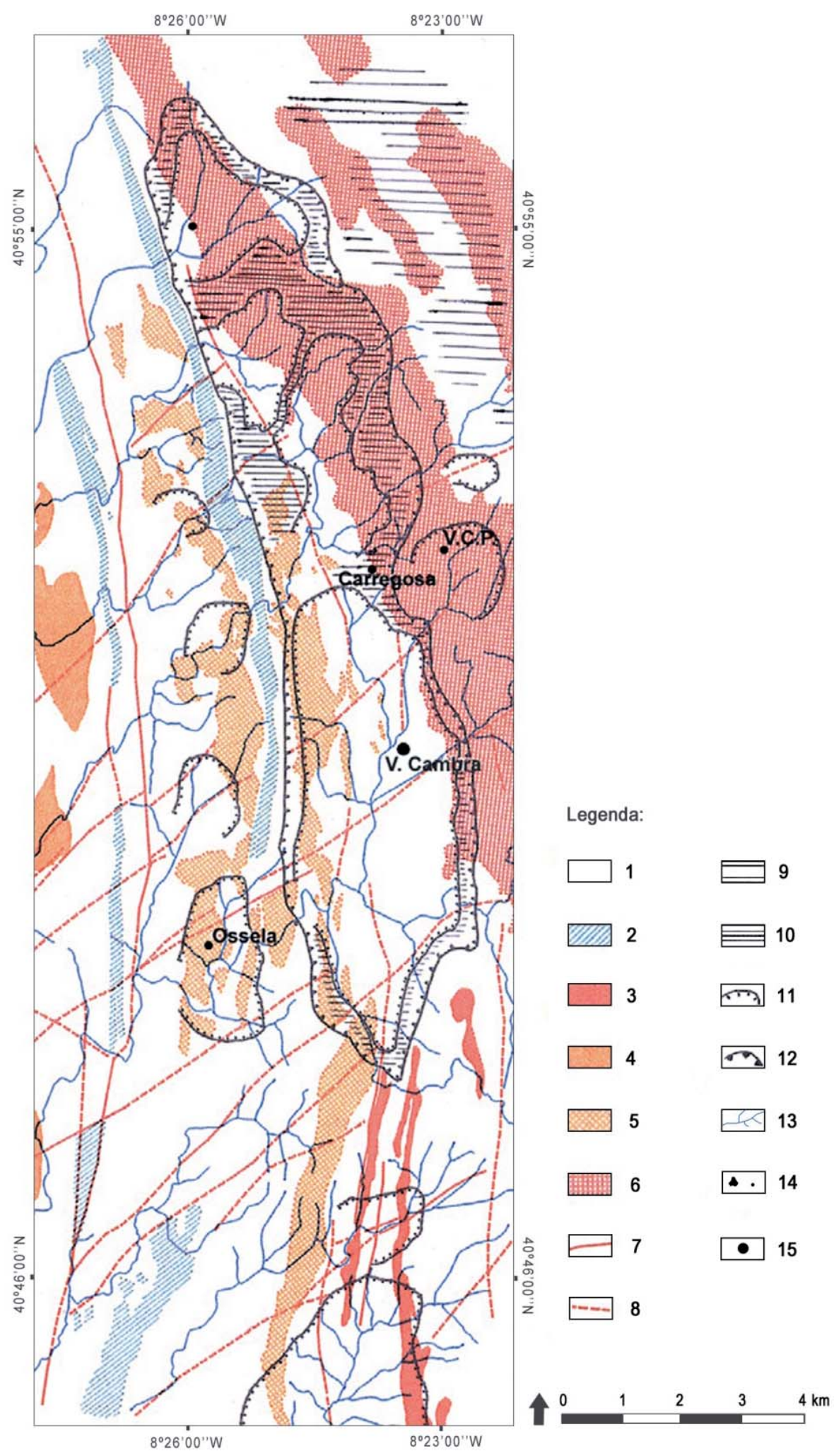

Figura 4 - Corredor de erosão de Vale de Cambra - Romariz

Legenda: 1 -Xistos, micaxistos e gnaisses de injeção; 2 - Cristas quartzíticas; 3 - Granitos do Arestal; 4 - Granitos da faixa blastomilonítica de Oliveira de Azeméis; 5 Gnaisses da faixa blastomilonítica de Oliveira de Azeméis; 6 - Granito de S. Pedro Velho-grão médio a grosseiro; 7 - Falha geológica; 8 - Fraturas e falhas prováveis; 9 - Níveis de Nabais; 10 - Níveis inferiores do corredor de erosão; 11 - Limites dos alvéolos elementares; 12 - Limite externo do corredor de erosão; 13 - Cursos de água; 14 - Marcos geodésicos e pontos cotados; 15 Povoações. 
Porém, a ação da tectónica é ainda realçada pela existência de inúmeras falhas e fraturas tanto perpendiculares como paralelas ao acidente principal, o que terá tornado esta vasta área num sector extremamente suscetível à meteorização química.

Por seu turno, o alvéolo de Arouca desenvolve-se, na sua totalidade, no quartzodiorito, apresentando como eixo principal um importante acidente tectónico com orientação E-W. Este acidente vai ser reforçado pela existência de um grande número de falhas e fraturas que se entrecruzam um pouco a ocidente da vila de Arouca, facto que terá mesmo motivado que o alvéolo apresente neste sector a sua largura máxima.

Aliás, no mesmo sentido observa-se a importância da tectónica em outros setores deste vasto território, como o referem VIEIRA (2008) para o Alvéolo de Feirão (serra de Montemuro) e CLAMOTE (2011) para o alvéolo de Penalobo (rebordo da superfície da Meseta).

\subsection{Os fatores morfoclimáticos}

A existência de rochas granitóides, suscetiveis à alteração, associada à presença de "alinhamentos" ou margens de rochas de maior resistência (cristas quartzíticas ou corneanas) e a existência de linhas de fragilidade tectónica, tornou, como referido, vastos sectores do Portugal Central como predispostos à alveolização.

Contudo, situações estruturais idênticas tanto a oeste como a oriente das Montanhas Ocidentais (Planaltos Centrais) estiveram na origem de alvéolos (ou muitas vezes depressões incipientes) tipologicamente diferenciados. Assim, três fatores parecem ter sido fundamentais para a amplitude e complexidade destas formas: a dimensão das bacias hidrográficas, a proximidade do mar e, em especial, as características climáticas (Cordeiro, 2004).

As linhas gerais das montanhas litorais no Cenozoico final, deveriam apresentar uma definição próxima da atual (o mesmo se observando relativamente à dinâmica atmosférica de ocidente), desempenhando um papel fundamental no desencadeamento de precipitações. Tal facto, tornava a água disponível como fator preponderante, quer para a meteorização (primeiro), quer para a evacuação dos materiais (depois).

Assim, nos sectores ocidentais das montanhas litorais, a existência de grandes quantitativos de precipitação motivaria uma elevada eficácia da meteorização química. Este facto seria reforçado pela proximidade do mar, o qual, em diferentes momentos do Pliocénico se encontraria mais para oriente (transgressões pliocénicas), dificultando a drenagem terminal dos cursos de água, provocando assim, uma maior eficácia da alteração química e a consequente amplitude das formas encontradas neste sector. Exemplo deste facto é a existência de níveis no interior dos alvéolos complexos (os "níveis inferiores" das Montanhas Ocidentais), que, apresentam diferentes características entre as vertentes orientais e ocidentais.

\section{Tipologia Alveolar do Centro-Norte de Portugal}

A existência de condições de base muito propícias à alveolização no setor a ocidente das Montanhas Ocidentais (o mesmo se observa a norte do rio Douro), tornaram ao longo das últimas décadas este setor como um dos territórios mais interessantes para a compreensão da génese e evolução das formas de degradação das superfícies aplanadas do Terciário, em particular no batólito quartzodiorítico de Arouca que oferece um quadro invulgar do ponto de vista pedagógico na exemplificação da génese e evolução do relevo alveolar do território português (Cordeiro, 1988; 1991; 1995b; 1995c; 2004).

Neste pequeno batólito desenvolvem-se três alvéolos de características topográficas diferentes: o de Moldes, de pequena dimensão, a Oriente; no setor central, o de Arouca, de grandes dimensões (ocupa mesmo grande percentagem de extensão do afloramento); a ocidente o de Rossas, já a jusante da "Pedra Má" (onde dominam as corneanas), aliás com características muito próximas do que é designado de "vale-alvéolo", onde a tectónica se apresenta como fator decisivo.

Porém, foram também identificadas formas alveolares no setor a ocidente do Maciço da Gralheira (área de Vale de Cambra), na serra de Montemuro e na serra do Caramulo, todas elas a integrar as Montanhas Ocidentais, assim como na Plataforma do Mondego e na Superfície da Meseta.

\subsection{Alvéolos elementares}

A forma mais simples (e também a mais frequente) da evolução do relevo em função dos processos morfogenéticos atrás descritos refere-se a pequenas depressões com uma forma em concha, com declives 
atenuados no sentido dos cursos de água. São os casos dos alvéolos de Moldes, de Vila Cova de Perrinho (Vale de Cambra), Almofala (serra do Caramulo) ou Água da Figueira (Meseta), entre muitas dezenas de pequenas depressões que degradam com maior ou menor eficácia os níveis aplanados envolventes, e que globalmente se integram no grupo daqueles que foram apresentados por Godard (1977) como "alvéolos elementares" (Figura 5).

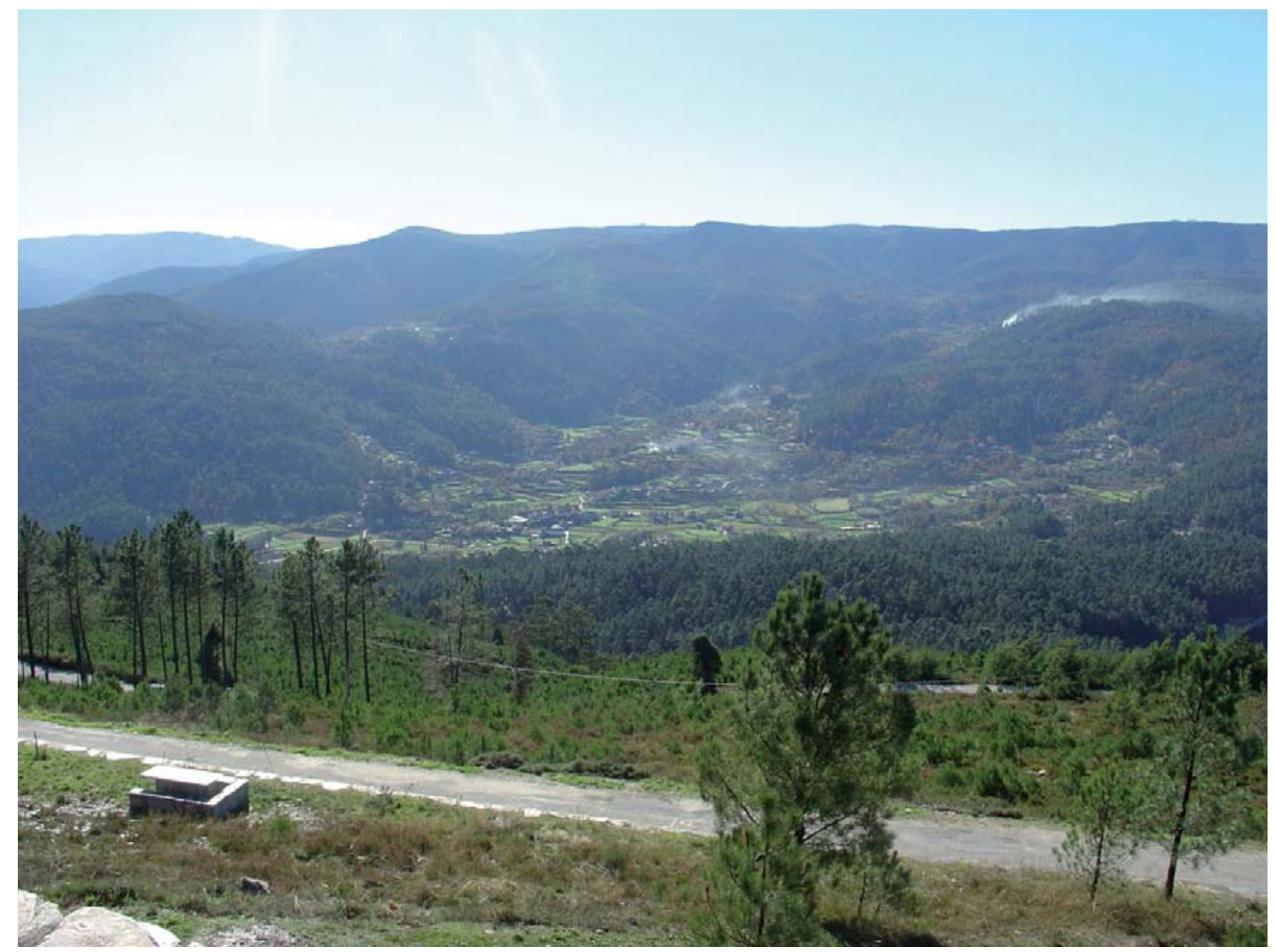

Figura 5 - Alvéolo elementar de Moldes (sector norte da serra da Arada/Freita).

Habitualmente referenciados como diretamente relacionados com pequenas diferenças petrográficas no seio dos batólitos ou áreas de maior fragilidade tectónica, estes alvéolos encontram-se por norma nos sectores marginais dos afloramentos graníticos ou dos níveis aplanados existentes e com uma relação estreita com os cursos de água, nos quais se encontram, usualmente, alcandorados.

No caso do sector ocidental do Maciço da Gralheira, este tipo de alvéolo mostra claramente o seu desenvolvimento em função da contínua ação da meteorização química da superfície aplanada de Nabais (setor aplanado dominante no setor ocidental das Montanhas Ocidentais), desenvolvida pelos 600/650 metros, uma vez que níveis aplanados com esta altimetria dominam estas formas - alvéolos de Vila Cova de Perrinho, Chave, Espinheiro e Canto, verificando-se situação muito semelhante na superfície da Meseta, como ilustra o alvéolo de Água da Figueira (Figura 6). Porém, no interior destes alvéolos não se encontram definidos quaisquer níveis.

\subsection{Alvéolos complexos}

De dimensões pluriquilométricas, no que contrastam com as dimensões da ordem das centenas de metros da tipologia anterior, os alvéolos designados por GODARD (1977) como "complexos", podendo ser identificados na serra de Montemuro - Alvéolo de Feirão (Vieira, 2008) -, na Meseta - Alvéolo de Penalobo (Clamote, 2011) - e na Plataforma do Mondego - alvéolo de Queirã (Cordeiro, 2004). Porém, este tipo apresenta um dos seus mais belos exemplos no "alvéolo de Arouca" situado, como vimos, no setor norte da serra da Arada/Freita (Figura 3 e Figura 7). 


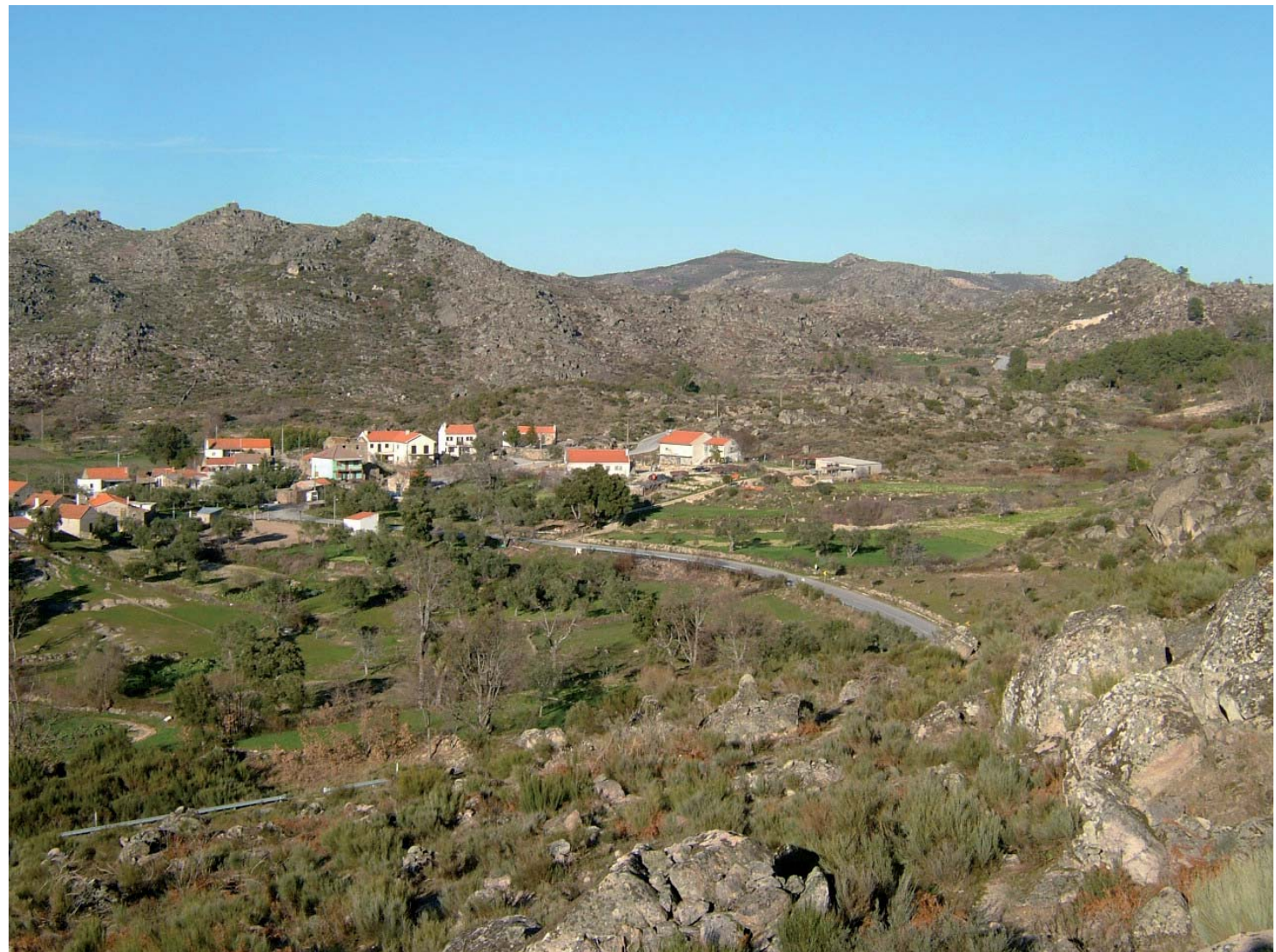

Figura 6 - Alvéolo elementar de Água da Figueira (rebordo sudoeste da superfície da Meseta).

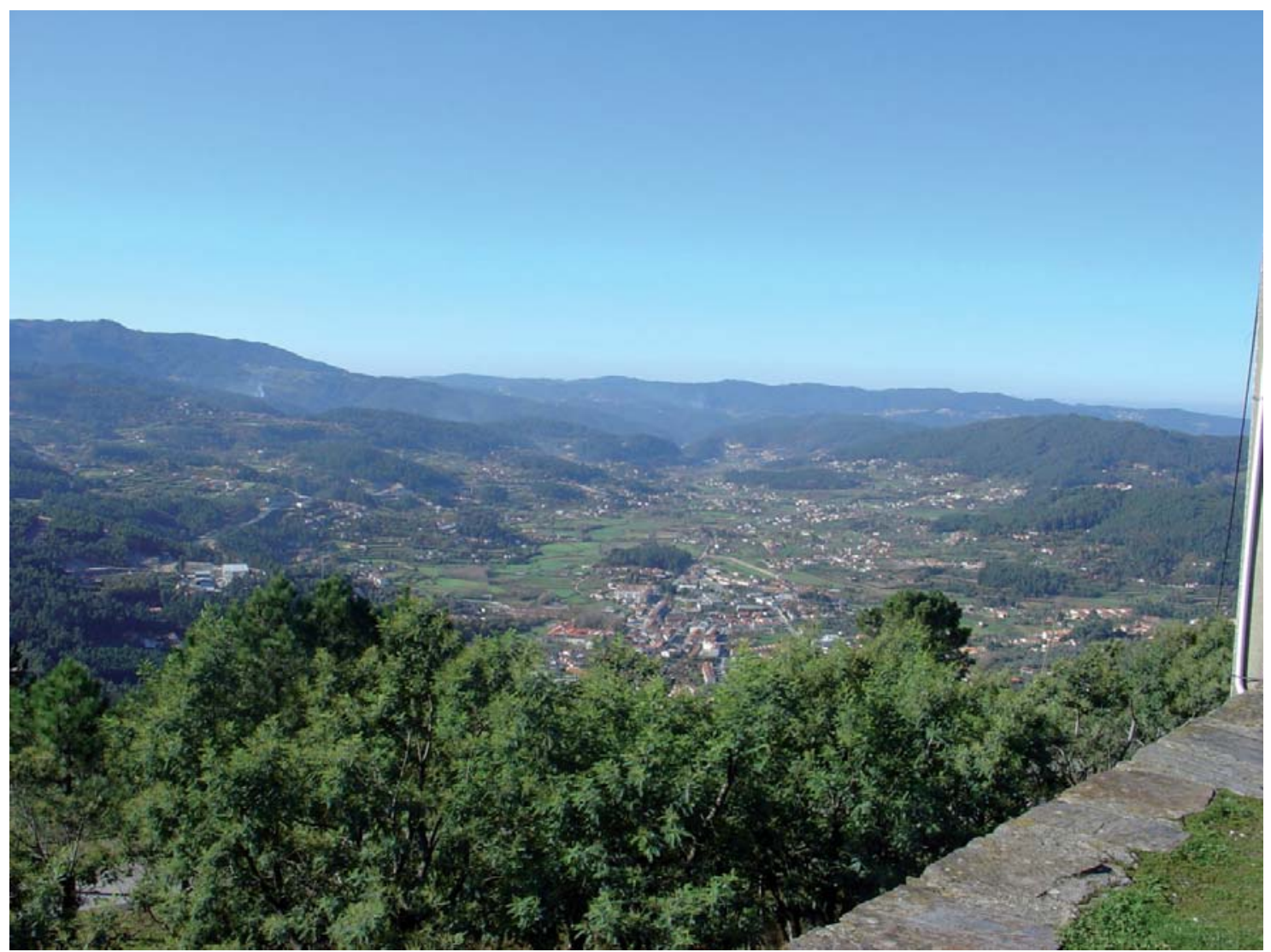

Figura 7 - Alvéolo de Arouca (fecha o horizonte a superfície de Nabais) 
Ocupando grande extensão da superfície do batólito, o alvéolo de Arouca vai apresentar características petrográficas de forte sensibilização à alteração, no que são reforçadas pela profusão de linhas de fragilidade tectónica, das quais a principal é a referida fratura de orientação E-O (cf. Figura 3). A meteorização química que se terá verificado com mais intensidade nos períodos quentes e húmidos encontraria, deste modo, condições estruturais para um ataque preferencial e com elevada eficácia. A existência, a jusante da depressão (área de contacto entre o batólito e os metassedimentos) de rochas de tipo corneana, que, por se apresentarem com grande dureza e pouco alteráveis, terá funcionado como obstáculo à drenagem para ocidente, motivando uma maior eficácia do processo de meteorização a montante.

No entanto, as diferenças entre alvéolos complexos e os elementares são bastante mais significativas que a simples dimensão: a existência de níveis de terraço fluvial no fundo de vale, como os níveis de erosão derivados da superfície de Nabais, os quais dominam claramente o alvéolo e cuja altimetria difere em função da natureza litológica onde se desenvolveram, é um desses fatores. Com os níveis que se desenvolvem em quartzodiorito a apresentarem valores entre os $450 \mathrm{e}$ os 480 metros e os que se desenvolvem em xistos e nas corneanas (área de Tropeço) situados, respetivamente a 500-520 metros e 590-600 metros, a ideia de uma meteorização química diferencial parece sair reforçada ${ }^{1}$ (Figura 3).

\subsection{Corredores de erosão}

Um dos melhores exemplos sobre o que ETLICHER (1985) designou como "corredores de erosão", é a depressão alongada que se desenvolve desde Romariz a Vale de Cambra (cerca de 16 quilómetros de eixo maior), localizado a ocidente da serra da Arada/Freita (Figura 8). Com o eixo principal a apresentar uma orientação NNO-SSE, determinado por importante acidente tectónico (falha de Milheirós de Poiares-Telhadela), este corredor desenvolveu-se num substrato rochoso de características complexas (faixa blastomilonítica de Oliveira de Azeméis) onde granitos, gnaisses, micaxistos e xistos são as rochas dominantes (Pereira et al., 1980) e onde a intensa fracturação vai fornecer condições de base estrutural, favoráveis ao desenvolvimento da alveolização (Figura 4).

Dominada a Oeste por uma pequena crista quartzítica que apresenta orientação paralela ao acidente tectónico principal e, a Nordeste e a Leste, respetivamente, pela superfície de Nabais e pela vertente ocidental do Maciço da Gralheira (serras da Arada/Freita e do Arestal), esta forma vai apresentar diferentes características relativamente às que foram definidas na tipologia dos alvéolos complexos.

A depressão, que hoje em dia é drenada por quatro cursos de água (os rios Caima, Antuã e Uima e a ribeira de Ul) que individualizam o mesmo número de alvéolos elementares (Vale de Cambra, Fajões, Romariz e Carregosa) apresenta, no entanto, um nível comum aos 350-380 metros (que dominam os pequenos alvéolos), relacionando-se este com o já referido nível inferior das Montanhas Ocidentais. Com descida suave de Norte para Sul, este nível corresponderia, num determinado momento, ao fundo do corredor de erosão, parecendo assim sugerir uma drenagem diferente da atual, com a existência de um único curso de água - o pré-Antuã? - a drenar para Sul (Cordeiro, 2004; Gomes, 2008). Drenagens idênticas foram apresentadas por REBELO (1975) como casos de adaptação dos cursos de água a cristas quartzíticas.

A existência de rochas granitóides e a intensa fracturação, aliada ao aparecimento no seu flanco ocidental de uma crista quartzítica, favoreceram, por um lado, uma importante meteorização química em tempos fini-terciários e, por outro lado, através da adaptação à estrutura, a determinação do seu traçado e a amplitude da forma. Os alvéolos elementares desenvolver-se-iam, assim, numa fase ulterior.

\subsection{Alvéolos mistos}

A apresentação deste tipo de alvéolos (aqui utilizando a designação em sentido lato) pretende dar resposta a uma situação, já referida a propósito dos corredores de erosão, que é a da existência de depressões do tipo alveolar em áreas onde a cartografia geológica não representa rochas granitóides. É um facto habitual, em trabalhos de áreas com características litológicas semelhantes, para designar formas deste tipo, no contacto entre rochas granitóides e rochas não granitóides.

${ }^{1}$ Refira-se igualmente a existência de um nível bem definido no interior do alvéolo, aos cerca de 300-350 metros, o qual foi considerado por FERREIRA (1978a), como um dos "níveis inferiores das Montanhas Ocidentais", e que constitui assim um bom fator diferenciador em termos de marcador paleogeográfico. 


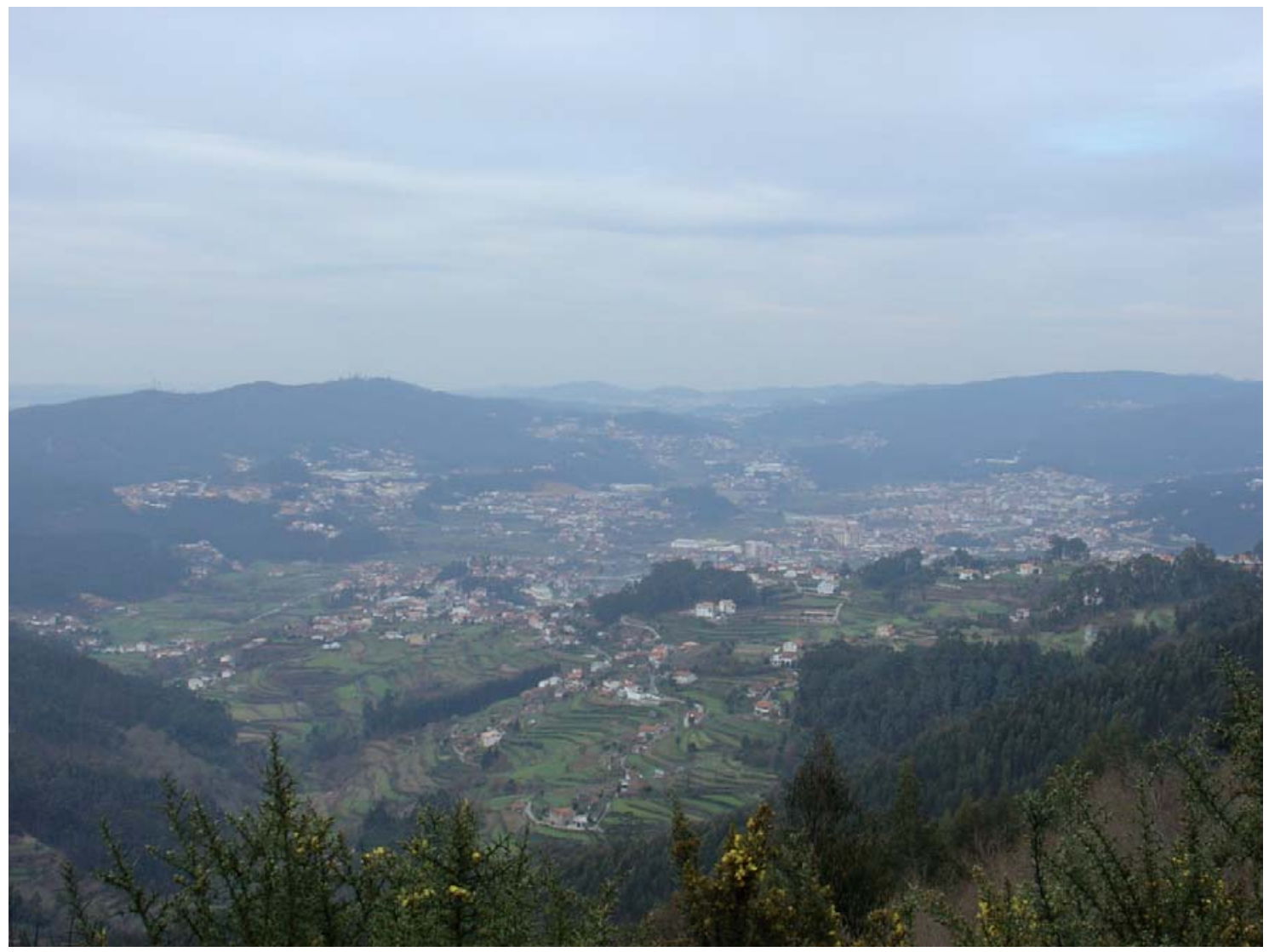

Figura 8 - Corredor de erosão de Vale de Cambra - Romariz

No caso das Montanhas Ocidentais, a mais bela forma deste tipo é o pequeno alvéolo de Linhares, (Serra do Arestal), que se desenvolve a partir da superfície dos 850 metros. Aqui, conjuga-se a existência de uma pequena mancha de quartzodiorito biotítico (a qual ocupa grande percentagem da área do alvéolo), de xistos afetados por fraturas e ainda o rebordo da grande mancha de granitos sintetónicos, o mesmo se observando nos alvéolos de Albergaria da Serra e Castanheira (superfície culminante da Serra da Arada/Freita). Também o alvéolo de Silva Escura (a sueste de Vale de Cambra) apresenta caraterísticas idênticas, embora neste caso, a existência de granitóides e/ou gnaisses ricos em biotite intercalados nos xistos (Pereira et al., 1980) ofereça uma forte originalidade à forma alveolar.

\section{Morfologia Alveolar nas Diferentes Unidades Morfológicas do Centro-Norte de Portugal e as Suas Etapas de Desenvolvimento.}

Os diferentes tipos de alvéolos observados neste sector do território português são formas resultantes de um mesmo processo conjunto, ou seja, da degradação das superfícies aplanadas desenvolvidas ao longo do Mesozoico e do Cenozoico. Porém, é com o deslocamento das superfícies terciárias por intervenção da tectónica, em particular a partir do Miocénico final que os diferentes condicionalismos para a sua evolução foram sendo clarificados.

O desnivelamento das superfícies por ação da tectónica terá sido responsável pela introdução de parâmetros como a altitude e o aparecimento de vertentes abruptas, os quais alteraram não só os fatores climáticos mas também o próprio posicionamento relativamente ao nível de base por um efetivo afastamento do mar para Ocidente. É esta conjugação de fatores que se assume como influência decisiva na eficácia do desenvolvimento e na diferenciação morfológica dos alvéolos.

Definem-se assim, três diferentes situações de desenvolvimento dos alvéolos, um pouco no seguimento da própria identificação das unidades morfológicas do centro-norte de Portugal. Deste modo, podem ser considerados os alvéolos de sopé de montanha, os de planalto e os de montanha.

Relativamente aos de sopé de montanha, e no 
que diz respeito aos alvéolos elementares (único tipo existente nos três sectores), deve ser realçado o facto de se observarem duas características particulares: por um lado, a sua forma em concha, com os declives das vertentes (assim como os dos perfis longitudinais dos cursos de água que os atravessam) a se apresentarem moderadamente significativos e, por outro, a cobertura das vertentes por parte das alterites, poucas vezes se verificando o aparecimento da rocha não alterada à superfície. Já quanto aos alvéolos complexos parece ser evidente que este é o grande domínio deste tipo de formas, em particular no sector ocidental do Maciço da Gralheira. Se os fatores estruturais existentes neste sector apresentam condições preferenciais ao desenvolvimento deste tipo de relevo, também não é menos verdade que os outros fatores referidos vão ter papel determinante nesse mesmo desenvolvimento.

Já quanto aos alvéolos de planalto, um facto deve, desde logo, realçar-se: a desnudação dos materiais nos pontos mais elevados das vertentes é uma situação evidente. Assim, tanto os alvéolos complexos como os próprios alvéolos elementares apresentam as vertentes dos seus sectores convexos sob a forma de caos de blocos ou "tors", enquanto os sectores mais baixos (fundo de alvéolo incluído), apresentam esses mesmos materiais alterados. Tal facto, dever-se-á a uma maior agressividade climática, a qual, através de processos ligados à escorrência, atuaria nos interflúvios motivando uma forte desnudação nos locais onde a própria alteração química terá sido menos intensa. Mas se os corredores de erosão nestes setores se apresentam incipientes (exceção feita ao de Feirão, na serra de Montemuro), os alvéolos elementares, por sua vez, vão apresentar dimensões significativas, alcandorados nos cursos de água, na maioria dos casos, e constatando-se que os declives, tanto dos cursos de água, como das vertentes, apresentam valores mais elevados do que nos restantes sectores.

Os alvéolos de montanha, e como seria espectável, vão apresentar características relativamente diferentes dos anteriores. Com menores dimensões, apresentam as vertentes praticamente desnudadas, encontrando-se os materiais alterados apenas nos fundos dos alvéolos. Estes são constituídos na sua grande maioria por materiais associados à dinâmica de vertentes em tempos mais recentes (Pleistocénico final e Holocénico). Os declives apresentam valores mais elevados relativamente aos dos alvéolos anteriormente analisados, uma vez que as vertentes, neste sector, se apresentam predominantemente convexas (ao contrário das anteriores, nos quais o sector côncavo é predominante), ainda que os declives dos cursos de água se mantenham atenuados (Figura 9).

A evolução do modelado alveolar apresenta no sector ocidental do Maciço da Gralheira condições propícias à tentativa de correlação (Cordeiro, 1995a; 2004). A superfície de Nabais (domina a norte o corredor de erosão de Vale de Cambra e a oeste o alvéolo de Arouca) representa uma fase de estabilidade a partir da qual se desenvolveu todo o relevo posterior. Com altimetria próxima dos 650 metros (quando bem conservada), FERREIRA (1978a) apresentou estes níveis como parte da superfície aplanada resultante dos aplanamentos Paleogénico e Miocénico. Poderá assim, corresponder ao que foi designado de momento inicial da evolução do relevo neste setor do litoral português (Cordeiro, 2004). A fase seguinte, ou seja, o início do processo de alveolização, refletiria um período compreendido entre o Miocénico superior e o Gelasiano (o início do Pleistocénico) e, no qual, em função da tectónica, as linhas de relevo ganhariam formas muito próximas das que se conhecem na atualidade. Neste mesmo período, as temperaturas deveriam ter sido relativamente elevadas, embora um arrefecimento gradual se viesse a verificar desde o início do Terciário, enquanto que a humidade, mesmo que, com períodos em que a aridez seria um facto inquestionável, apresentar-se-ia nos restantes e longos períodos com valores relativamente elevados.

As condições globais apresentar-se-iam, deste modo, propícias ao desenvolvimento da meteorização química das rochas granitóides, verificando-se assim, no decorrer de um largo período, condições propícias ao desenvolvimento dos mantos de alteração, em função do aprofundamento da superfície basal de meteorização. Deste facto, resultaria não só o significativo alargamento e aprofundamento do sector fragilizado pelo entrecruzamento tectónico, mas também o aparecimento de níveis que circundam os alvéolos complexos. Estes níveis, que se encontram a diferentes altitudes no caso de Arouca (Figura 3), resultavam de uma mais intensa meteorização química do quartzodiorito.

A terceira fase corresponderia aos momentos de evacuação dos materiais anteriormente alterados. Para tal, a necessidade da existência de condições climáticas propícias à saída espasmódica dos materiais (grandes quantitativos de precipitação concentrados em curtos períodos) e um significativo abaixamento do nível de 


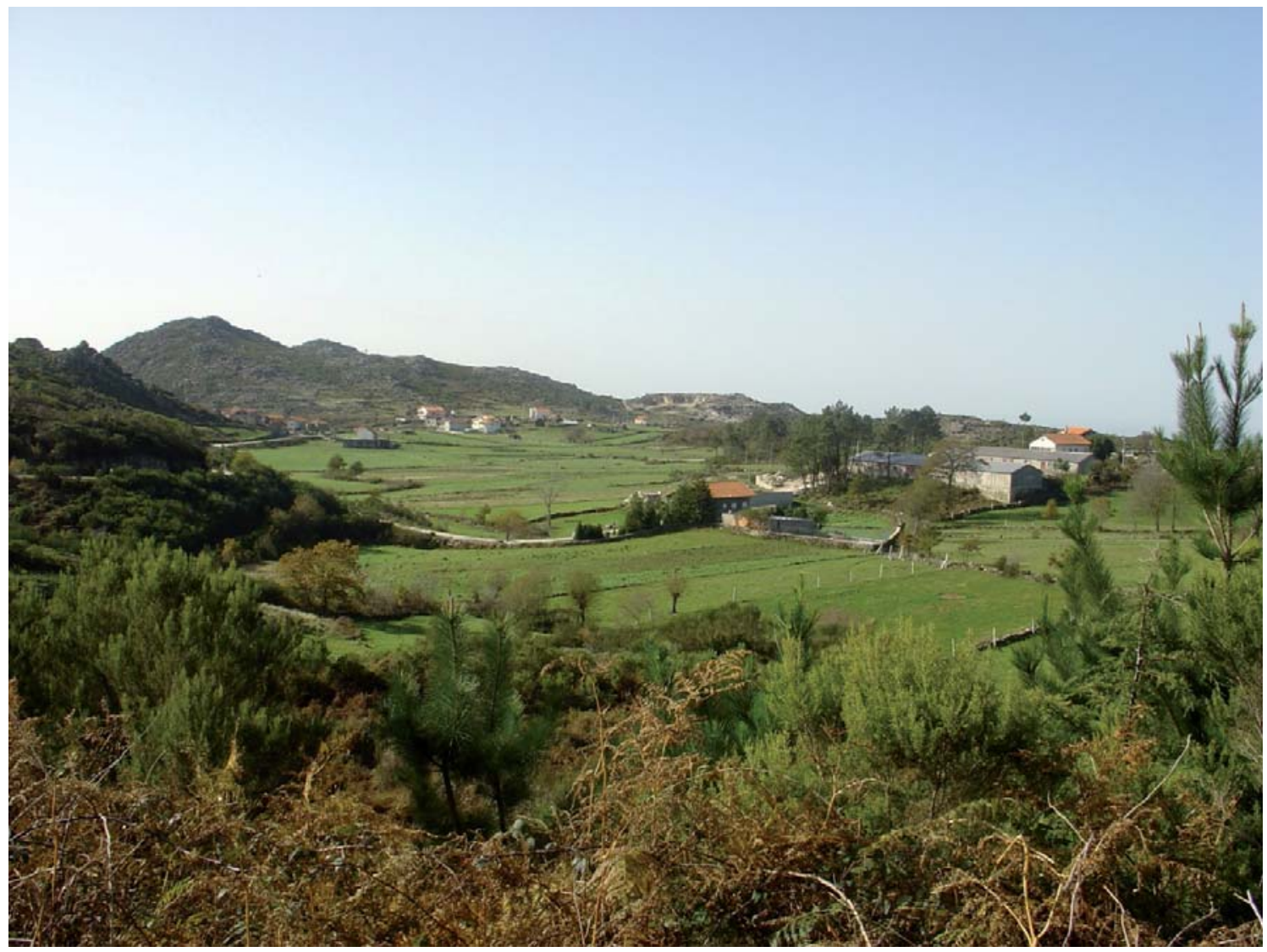

Figura 9 - Alvéolo de Almofala (serra do Caramulo)

base, são factos fundamentais. Assim, e de imediato, estas características levariam a relacionar esta terceira fase com o "Terciário" final ou com o limite PlioPleistocénico. Nesse sentido, uma outra fase pode ser considerada na evolução alveolar, tendo em consideração o constatado no corredor de erosão de Vale de Cambra - Romariz: após a fase de estabilidade que terá estado na origem dos níveis de 350-380 metros (calabrianos?) individualizaram-se os já referidos alvéolos elementares no interior do corredor de erosão. Assim, a existência de uma quarta fase, na qual se terá verificado uma mudança radical da rede de drenagem, de uma só bacia hidrográfica para quatro pequenas bacias individualizadas julga-se também ser um facto a considerar já que se vai observar a continuação do processo de alveolização ao longo do quaternário.

\section{Alguns aspetos conclusivos}

O modelado de degradação das superfícies aplanadas, mais concretamente os "alvéolos" da escola francesa (Godard, 1977), reflete um somatório de fatores interdependentes, que forneceram à morfogénese do "Terciário" final no Portugal Central (sempre associado ao desenvolvimento de superfícies aplanadas e da sua movimentação por parte da tectónica alpina) um cunho muito particular.

A importância do fator litológico é perfeitamente visível, já que o aparecimento de alvéolos se relaciona, no essencial, com granitóides de forte componente ferromagnesiana. Constatou-se assim, que o maior número destas formas se encontra relacionado com os granitóides biotíticos, associado sempre à existência de um forte controle tectónico. No entanto, e paralelamente, outros fatores tais como a textura, a porosidade e a microfissuração vão também, pela sua interação, oferecer aos sectores ocidental e setentrional do Maciço da Gralheira condições ótimas do ponto de vista litológico e tectónico, para o desenvolvimento do relevo com génese associada à erosão diferencial.

A estes argumentos de base estrutural, que foram considerados como parâmetros fundamentais na sua génese, vai associar-se a necessidade da atuação da alteração química em momentos de clima quente hú- 
mido, o que fornece um contexto desigual na eficácia desse processo morfogenético nos diferentes setores do território. Neste quadro, a dicotomia existente entre o litoral e o interior (cujo limite poderá ser conferido pelas altitudes com maiores valores das montanhas litorais) fornece uma importância decisiva aos argumentos morfoclimáticos no desenvolvimento e na definição das formas. Assim, e por força dos climas do terciário, quer na fase de meteorização, quer na fase de exumação dos criptorelevos, observou-se o desencadeamento de diferentes processos morfogenéticos que conduziram a este modelado. Numa primeira e longa fase, de características climáticas quentes e húmidas (do miocénico ao placenciano - ?), as caraterísticas climáticas conduziram a uma intensa alteração dos minerais mais instáveis, com um consequente aprofundamento da superfície basal de meteorização (em função de um crescendo da arenitização). Já a segunda fase (do gelasiano ao início do pleistocénico - ?), apresentando características de incremento de aridez e arrefecimento, e com a possível orrência de chuvas concentradas, estas poderiam estar na origem da saída espasmódica dos materiais alterados anteriormente.

A observação atenta da morfologia de média escala associada à degradação das superfícies aplanadas, permitiu a constatação da existência de diferentes tipos de alvéolos - elementares, complexos, corredores de erosão, e mesmo em alvéolos mistos -, os quais, por seu turno, mostram a relação existente entre todos os fatores de base e os processos envolvidos na alveolização. A génese e definição destas formas pode assim ser assumida como o compromisso entre os fatores estruturais e os fatores morfoclimáticos, razão pela qual parecem apresentar uma espacialização e uma eficácia menos significativa nos territórios do interior do Portugal Central.

\section{Referências Bibliográficas}

BIROT, P. Les surfaces d'érosion du Portugal central et septentrional - Rapport de la Comission pour la cartographie des surfaces d'érosion, Congr. Internat. Geographie, Lisboa, 1949, p. 9-116.

BIROT, P.; DAVEAU, S.; A. B. FERREIRA; GODARD, A.; GRELOU-ORSINI, C. e RIBEIRO, O., "Compte rendu d'une excursion de geomorphologie dans le Portugal central (mai 1976)". Mediterranée, 3, 1979, p. 59-70.
BÜDEL, J. "Pedimente, Rumpflachen und BucklandSteilhange”, Geomorph. N. F., 2, 14, 1970, p. 1-57.

CLAMOTE, V. O desnivelamento entre a superfície da Meseta e as superfícies abatidas da Beira Baixa Compreensão geomorfológica da sua evolução - Dissertação de Mestrado, FLUC, Coimbra, 2011, 111 p.

COQUE-DELHUILLE, B. "Indice d'altérabilité potentielle approchée des roches granitoîdes”, Physio-Géo, n 2, Paris, 1981, p. 59-70.

CORDEIRO, A. M. Rochette Evolução das Vertentes da Serra da Freita. Monografia para Provas de Aptidão Pedagógica e Capacidade Científica, FLUC, Coimbra, 1986, 164 p.

CORDEIRO, A. M. Rochette A evolução das vertentes da Serra da Freita no Quaternário recente. Cadernos de Geografia, $n^{\circ} 7$, Coimbra, 1988, p. 87-113.

CORDEIRO, A. M. Rochette Alguns aspectos da morfologia granítica do Maciço da Gralheira. Livro-guia da viagem de estudo à serra da Freita, IV Semana de Geografia Física, IEG, Coimbra, 1991, 45 p.

CORDEIRO, A. M. Rochette Alvéolos graníticos do CentroNorte de Portugal. Génese e tipologia". Actas do VI Colóquio Ibérico de Geografia, 1992, Porto, 1995a, p. 689-697.

CORDEIRO, A. M. Rochette O peso do factor estrutural no desenvolvimento do relevo granítico à erosão diferencial. (O exemplo dos alvéolos de Centro-Norte de Portugal). Actas do VI Colóquio Ibérico de Geografia, 1992, Porto, 1995b, p. 699-706.

CORDEIRO, A. M. Rochette O modelado granítico de pormenor nas Montanhas Ocidentais do Portugal Central. Tentativa de sistematização. Actas dos Encontros de Geomorfologia, FCTUC, Projeto Praxis XXI - 2/2.1/CTA/156/94, Coimbra, 1999a, p. 35-44.

CORDEIRO, A. M. Rochette Uma nova perspectiva sobre os critérios de definição para as microformas graníticas. $\mathrm{O}$ caso das Montanhas Ocidentais do Portugal Central. Actas dos Encontros de Geomorfologia, FCTUC, Projeto Praxis XXI 2/2.1/CTA/156/94, Coimbra, 1999b, p. 31-34.

CORDEIRO, A. M. Rochette Dinâmica de vertentes em montanhas ocidentais do Portugal Central. Dissertação de Doutoramento em Geografia, FLUC, Coimbra, 2004, 566 p.

CORDEIRO, A. M. Rochette e REBELO, F. M. S. Carta Geomorfológica do Vale do Côa a Jusante de Cidadelhe". Cadernos de Geografia, no ${ }^{\circ}$ 15, 1996, Coimbra, 1996, p. 11-33. 
CORDEIRO, A. M. Rochette, ClAMOTE, V., REBELO, F. O peso da estrutura como explicação dos blocos graníticos paralelepipédicos da Serra das Mesas - Revista da Associação Portuguesa de Geomorfólogos - Vol. V - Lisboa, 2007, pp. 211-220.

COUdÉ-Gaussen, G. Les Serres da Peneda et do Gerês. Étude geomorphologique, Memórias do CEG, Lisboa, 1981, $254 \mathrm{p}$.

CUNHA, P. Estratigrafia e sedimentologia dos depósitos do Cretácico superior e Terciário de Portugal Central, a Leste de Coimbra. Tese de Doutoramento, FCTUC, Coimbra, 1992, $262 \mathrm{p}$.

ETLICHER, B. Quelques types d'alvéoles et de couloires dans l'Est du Massif Central", Physio-Géo, na 13, Paris, 1985, p.19-29.

FEIO, M. e BRITO, R. S. Les valées de fracture dans le modelé granitique portugais“.Congrès Internationale de Géographie, tome II, Lisboa, 1949, p. 254-262.

FERREIRA, A. B. Planaltos e Montanhas do Norte da Beira. Estudo de Geomorfologia. Memórias do CEG, nº 4, Lisboa, 1978a, 374 p.

FERREIRA, A. B. Erosão diferencial e modelado das regiões graníticas do Norte de Portugal. Linha de acção de Geog. Física, rel. no 7, CEG, Lisboa, 1978b, 88 p.

FERREIRA, A. B. Surfaces d'aplanissement et tectonique recente dans le Nord de la Beira (Portugal), Revue de Géologie Dynamique et de Géographie Physique, vol. 22, fasc. 1, Paris, 1980, p. 51-62.

FERREIRA, A. B. L'évolution tectonique tertiaire dans le nord-ouest du Portugal. L'apport des méthodes géomorphologiques. Linha de ação de Geografia Física, relatório $\mathrm{n}^{\mathrm{0}}$ 26, CEG, Lisboa, 1986, 26 p.

FERREIRA, A. B. Neotectonics in Northern Portugal. A Geomorphological approach. Zeitschrift fur Geomorphologie, N.F., Suppl. Bd 82, Berlin, 1991, pp. 73-85.

GODARD, A. Pays et paysages du granite. PUF, Paris, 1977, $232 \mathrm{p}$.

GODINHO, M. M. O plutonito do Caramulo, Memórias e Noticias do Museu Min. da Universidade de Coimbra, $\mathrm{n}^{\circ}$ 89-90, Coimbra, 1980, p. 1-269.

GOMES, A. A. T. Evolução Geomorfológica da Plataforma Litoral entre Espinho e Águeda. Dissertação de Doutoramento, FLUP, Porto, 2008, 337 p.
LAGASQUIE, J. J. Géomorphologie des Granites. Les massifs granitiques de la moitié orientale des Pyrénées françaises. CNRS, Paris, 1984a, 374 p.

LAGASQUIE, J. J. Le poids des faits structuraux dans les paysages granitiques Pyrenées, Physio-Géo, nº 10, Paris, 1984b, p. $117-121$

PEDROSA, A. S. Um caso particular de erosão dos granitos na Serra do Marão, Cadernos de Geografia, IEG, $n^{\circ}$ 10, Coimbra, 1991, p. 199-207.

PEDROSA, A. S. A Serra do Marão. Estudo de Geomorfologia. Tese de Doutoramento, FLUP, Porto, 1993, 478 p.

PEREIRA, E.; GONÇALVES e MOREIRA Notícia explicativa da folha 13-D (Oliveira de Azeméis). Serviços Geológicos de Portugal, Lisboa, 1980, 68 p.

PINTO, M. S. Granitóides dos Maciços de Arouca e Regoufe: dados geoquímicos e isotópicos e algumas implicações. Comunicações dos Serviços Geológicos de Portugal, tomo 71, fasc. 2, Lisboa, 1985, p. 159-169.

REBELO, F. M. S. Serras de Valongo. Estudo de Geomorfologia, Coimbra, 1975, 194 p.

REBELO, F. M. S. Considerações gerais sobre o relevo granítico em Portugal, Cadernos de Geografia, nº 19, Coimbra, 1991, p. 521-535.

REBELO, F. M. S. e CORDEIRO, A. M. Rochette A Geomorfologia e a Datação das Gravuras de Foz Côa Metodologia e Desenvolvimento de um Caso de Investigação Científica. Finisterra, XXXII, 63, Lisboa, 1997, p. 95-105.

RIBEIRO, O. Le Portugal Central (Livret-Guide de l'excursion C), XVI Congrès Internationale de Géographie, Lisboa, 1949, 180 p.

RIBEIRO, O. Estrutura e relevo da Serra da Estrela, Boletín de la Sociedad Española de Historia Natural, Madrid, tomo de Homenage a E. Hernandez-Pacheco, 1954, p. 549-566.

ROMANI , J. V. e TWIDALE, C. R. Formas y paisajes graníticos, Ed. Universidade da Coruña, 1998, 411 p.

SOARES, L. As Serras de Campelos e Maragotos. Contributo para um estudo de morfologia granítica. Tese de Mestrado, FLUC, Coimbra, 1992, 146 p.

THOMAS, M.F. Tropical Geomorphology - A study of weathering and landform development in warm climates. London, 1974, 332 p.

THOMAS, M.F. Geomorphology in the Tropics - A study 
of weathering and Denudation in Low Latitudes. Wiley, Chichester, 1994, $460 \mathrm{p}$.

TWIDALE, C. R. Granites Landforms. Elsevier, Amsterdam, 372 p. 1982.

TWIDALE, C. R. The two-stage concept of landform and landscape development involving etching: origin, development and implications of an idea, Earth-Science Reviews, 57, ed. 1-2, 2002, p. 37-74.
VIEIRA,A. Serra de Montemuro: Dinâmicas Geomorfológicas, Evolução da Paisagem e Património Natural, Dissertação de Doutoramento, Universidade de Coimbra, 2008, 689 p.

VIEIRA, A. Património geomorfológico na Serra de Montemuro. Valor e diversidade da morfologia granítica. In Dinâmicas de rede no turismo cultural e religioso - II Jornadas Internacionais de Turismo, ed. Eduardo Gonçalves, Maia, Edições ISMAI, 2010, p. 187-203. 